Pediat. Res. 7: 1-4 (1973)

Developmental biochemistry

fetus

liver neonate

phenylalanine hydroxylase

\title{
Phenylalanine Hydoxylase in Human Liver during Development
}

\author{
NIELS C. R. RÄIHÄ[21] \\ Departments of Medical Chemistry and Pediatrics, University of Helsinki, Helsinki, Finland
}

\begin{abstract}
Extract
Phenylalanine hydroxylase activity is present in the liver of human fetuses after the 8th week of gestation, and activities similar to those found in liver from adult control subjects are reached at around the 13th fetal week. The mean enzyme activity in fetal liver after the 13th week of gestation was $107 \mu$ moles tyrosine formed per g protein per hr, and $130 \mu$ moles in livers from adult control subjects. In premature infants soon after birth the mean enzyme activity was $67 \mu$ moles tyrosine formed. This difference from the level of activity in fetuses could be due to loss of activity during the 1-3-hr delay in obtaining liver samples after death. When the pteridine cofactor was omitted from the enzyme assay system only very low activity was found in the livers of fetuses which were studied. Tyrosine was formed when isolated fetal livers were perfused with phenylalanine. The $K_{m}$ for phenylalanine hydroxylase from the liver of human fetuses was $9 \times 10^{-4} \mathrm{M}$ and for liver from adults was $1 \times 10^{-3} \mathrm{M}$. Thus, the human fetus and immature newborn infant do not lack phenylalanine hydroxylase in the liver.
\end{abstract}

\section{Speculation}

The human fetus and immature newborn infant have considerable phenylalanine hydroxylase activity in the liver. The hyperphenylalaninemia or reduced tolerance for phenylalanine found in some infants with low birth weight should thus, not be paralleled with a transient form of phenylketonuria, but could rather be caused by a reduced efficiency of some other component of the phenylalanine-hydroxylating system.

\section{Introduction}

In liver from adult mammals, tyrosine is formed by a complex enzyme system which converts the essential amino acid, phenylalanine, to tyrosine. This system consists of several enzymes and cofactors and the final reaction forming tyrosine requires the enzyme, phenylalanine hydroxylase (EC. 1.99.1.2), and a tetrahydropterin cofactor [8]. Four reports concerning the activity of phenylalanine hydroxylase during human development appear in the literature. Kenney and
Kretchmer [10] reported the absence of the enzyme in one premature infant studied at necropsy, Ryan and Orr [16] reported the formation of some ${ }^{14} \mathrm{C}$-tyrosine after postmortem injection of ${ }^{14} \mathrm{C}$-phenylalanine into the umbilical vein of 22- week-24-week-old fetuses. During the course of the present study, Friedman and Kaufman [4] reported the presence of phenylalanine hydroxylase activity in the liver of one 23-week-old human fetus after storage of the liver for 4 weeks at $-80^{\circ}$, and Jakubovic [6] also found phenylalanine hy- 
droxylase present in the liver of seven human fetuses of between 11 and 20 weeks gestational age. In the present study the phenylalanine hydroxylase activity has been studied in liver from fetuses, neonates, and adult humans, and the tyrosine-forming capacity of isolated liver from human fetuses has been investigated.

\section{Material and Methods}

The phenylalanine hydroxylase activity was studied in 18 fresh livers from human fetuses $(2.0-21.0 \mathrm{~cm}$ crownrump length), obtained by therapeutic abortion, in five premature neonates who died between 1 and 10 days after birth and in whom the liver sample was obtained $3 \mathrm{hr}$ or less after death. The control material

Table I. Development of phenylalanine hydroxylase activity in human liver

\begin{tabular}{|c|c|c|}
\hline \multicolumn{2}{|c|}{ Adult } & \multirow{2}{*}{$\begin{array}{l}\text { Tyrosine formed, } \\
\mu \text { moles/g protein/hr }\end{array}$} \\
\hline Age, yr & Sex & \\
\hline 22 & female & 130 \\
\hline 42 & female & 136 \\
\hline 54 & male & 154 \\
\hline 72 & male & 140 \\
\hline 78 & female & 93 \\
\hline \multicolumn{2}{|c|}{ Fetal } & \\
\hline Gestation, wk & $\begin{array}{l}\text { Crown-rump } \\
\text { length, } \mathrm{cm}\end{array}$ & \\
\hline 7 & 2.0 & 0 \\
\hline 8 & 5.0 & 100 \\
\hline 10 & 5.5 & 74 \\
\hline 12 & 7.0 & 83 \\
\hline 13 & 9.0 & 172 \\
\hline 13 & 10.0 & 73,110 \\
\hline 14 & 11.5 & 100 \\
\hline 15 & 12.0 & 100 \\
\hline 16 & 13.0 & 100,135 \\
\hline 18 & 16.0 & 190 \\
\hline 18 & 16.0 & 60 \\
\hline 19 & 17.0 & 85 \\
\hline 21 & 20.0 & 67,78 \\
\hline 22 & 21.0 & 86,144 \\
\hline \multicolumn{2}{|c|}{ Newborn } & \\
\hline Age, day & Weight, $\mathrm{g}$ & \\
\hline 1.5 & 780 & $86(1.5)^{1}$ \\
\hline 3 & 1,780 & $73(1)$ \\
\hline 1 & 2,250 & $30(3)$ \\
\hline 6 & 2,600 & 54 (1) \\
\hline 1 & 2,950 & $90(1)$ \\
\hline
\end{tabular}

1 Numbers in parentheses indicate the time, in hours, after death at which the liver samples were excised. consists of liver tissue obtained by abdominal surgery from adult patients of varying ages. The liver tissue was homogenized in $0.15 \mathrm{M} \mathrm{KCl}$ and certifuged for 20 $\min$ at $6000 \times g$. The supernatant fluid was used for the enzyme assay. Phenylalanine hydroxylase activity was measured immediately by a modification of the methods described by Kaufman [7] and Bublitz [3]. The assay contained the following components (in micromoles): potassium phosphate, $\mathrm{pH} 6.8,30$; L-phenylalanine ${ }^{-14} \mathrm{C}, 0.4(0.2 \mu \mathrm{Ci})$; dimethyltetrahydropteridine, 0.12; dithiothreitol, 2; 0.01-0.05 ml liver extract and water to a final volume of $0.2 \mathrm{ml}$. Tyrosine formation was assayed according to the method described by Kaufman [7]. The soluble protein concentration was measured [14] and enzyme activity was expressed as micromoles tyrosine formed per hour per gram soluble protein. In addition to these enzymatic studies, two isolated livers from fetuses with a crown-rump length of 11 and $17 \mathrm{~cm}$ were perfused with L-phenylalanine- ${ }^{14} \mathrm{C}$ using the methods described by Kekomäki et al. [9], and the tyrosine formation was measured.

\section{Results}

The in vitro studies on phenylalanine hydroxylase using an excess of reduced pteridine cofactor showed that liver from human fetuses contained measurable activity after the 8 th week of gestation and values similar to those found in the adult control livers were reached at about 13 weeks (Table I). When the pteridine cofactor was omitted from the assay system only very low phenylalanine activity was found in the fetal livers studied. Livers of neonates studied showed enzyme activities similar to those of the late fetal and adult livers regardless of birth weight and gestational age (Table I). If liver samples were obtained later than 3 hours after death low enzyme activity was found.

Phenylalanine hydroxylase from the liver of human fetuses showed a rapid loss of activity when the liver was kept in room temperature after excision but could be stored at $-80^{\circ}$ over night without activity loss. Enzyme activity was reduced by about $25 \%$ in $3 \mathrm{hr}$ and by $50 \%$ in $6 \mathrm{hr}$ in tissue kept at room temperature. To see whether the enzyme in liver from human fetuses was different from that of liver from adults, the apparent $K_{m}$ values for phenylalanine were determined (Fig. 1). The $K_{m}$ for phenylalanine hydroxylase of liver from human fetuses was $9 \times 10^{-4} \mathrm{M}$ and for liver from adults $1 \times 10^{-3} \mathrm{M}$.

The two perfused livers from fetuses had a maximum formation of tyrosine $30 \mathrm{~min}$ after the start of the 
perfusion which was 160 and $370 \mathrm{~m} \mu$ moles tyrosine/ min, respectively. At the concentration of substrate used in the medium, this was of the order of magnitude expected from the enzyme assay performed after the perfusion. The addition of tetrahydropteridine to the perfusate did not increase the formation of tyrosine.

\section{Discussion}

The phenylalanine hydroxylase activity found in the liver from a 23-week-old human fetus studied by Friedman and Kaufman [4] was $0.043 \mu$ moles/mg protein/ $30 \mathrm{~min}$ and corresponds well with the values found in fetal liver in the present study. It is thus evident that phenylalanine hydroxylase activity in liver from the human fetus is present much before term. The activities in the livers of the neonates who were studied after death were in general somewhat lower than those. found in livers from fetuses in the late gestational stage and livers from adult control subjects. This could have been due to the 1-hr-3-hr delay in obtaining liver samples, since it was demonstrated clearly that the enzyme activity was lost rapidly at room temperature.

Clinical studies of the phenylalanine-hydroxylating capacity of the neonate are somewhat conflicting. Thus, some studies have reported elevated levels of phenylalanine in the blood of many premature and some full-term neonates $[5,11,15]$, and decreased tolerance for phenylalanine loads in the normal neonate have been reported by Bremer and Neumann [1]. The elevated concentrations of phenylalanine in blood found in these infants have generally been explained as being due to a transient low activity of phenylalanine hydroxylase. On the other hand, Levine et al. [12] have demonstrated that after administration of phenylalanine there is an increased excretion of tyrosine in the urine in both premature and full-term neonates and Menkes and Avery [15] have found normal phenylalanine tolerance tests in premature neonates. Both findings are consistent with an active phenylalanine hydroxylase system.

Light et al. [13] observed moderate elevation of concentrations of phenylalanine in serum which was associated with a marked elevation of tyrosine in serum in $25 \%$ of infants with low birth weight. Levels of both phenylalanine and tyrosine in serum returned to normal when $100 \mathrm{mg}$ ascorbic acid was administered daily. Distinction from patients with phenylketonuria was possible by recognition of elevated levels of tyrosine and by response to administered ascorbic acid.

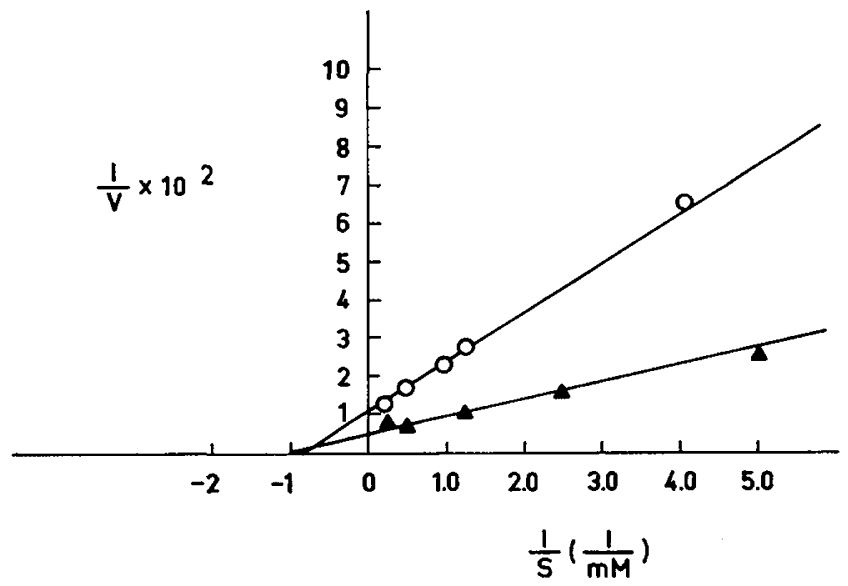

Fig. 1. Effect of L-phenylalanine concentration of the rate of tyrosine formation by human fetal $(\mathrm{O})$ and adult $(\boldsymbol{\Delta})$ phenylalanine hydroxylase from liver (double reciprocal plot). The incubation conditions were described in Materials and Methods, except for varied phenylalanine concentrations.

The present study indicates that phenylalanine hydroxylase is present in the liver from a very early stage of human development. The hyperphenylalaninemia observed in many premature infants for some time after birth should thus not be paralleled with a transient form of phenylketonuria (i.e., phenylalanine hydroxylase deficiency), but could rather be caused by excessive feeding of protein or to a relative deficiency of pteridine cofactor or dihydropteridine reductase. In the neonatal rat pterin cofactor and dihydropteridine reductase have been found to be low [2]. Snyderman [17] has been able to obtain data based on studies on weight gain and nitrogen retention which indicate that tyrosine is a dietary requirement for the majority of premature infants and that this requirement persists for several months after birth. These results suggest that the phenylalanine-hydroxylating system is deficient in the premature infant although the enzyme, phenylalanine hydroxylase, is present and suggest also that tyrosine might be an essential amino acid for the infant of low birth weight.

\section{References and Notes}

1. Bremer, H. J., and NeumanN, W.: Phenylalanin-Toleranz bei Frühgeborenen, reifen Neugeborenen Säuglingen und Erwachsenen. Klin. Wschr., 44: 1076 (1966).

2. Brenneman, A. R., AND Kaufman, S.: Characteristics of the hepatic phenylalanine hydroxylating system in newborn rats. J. Biol. Chem., 240: 3617 (1965).

3. Bublitz, C.: A direct assay for liver phenylalanine hydroxylase. Biochim. Biophys. Acta, 191: 249 (1969).

4. Friedman, P. A., and Kaufman, S.: A study of the development of phenylalanine hydroxylase in fetuses of several mammalian species. Arch. Biochem. Biophys., 146: 321 (1971). 
5. Hsia, D. Y. Y., Litwack, M., O'FlynN, M., and Jakovicic, S.: Serum phenylalanine and tyrosine levels in the newborn infant. New Engl. J. Med., 267: 1067 (1962).

6. Jakubovic, A.: Phenylalanine-hydroxylating system in the human fetus at different developmental ages. Biochim. Biophys. Acta., 237: 469 (1971).

7. Kaufman, S.: Phenylalanine hydroxylase in human liver: assay and some properties. Arch. Biochem. Biophys., 134: 249 (1969).

8. KaUfman, S.: The phenylalanine hydroxylating system from mammalian liver. Advan. Enzymol., 35: 245 (1971).

9. Кекомӓкr, M., Seppälä, M., Ehnholm, C., Schwartz, A. L., and RaIvio, K.: Synthesis and release of plasma proteins by isolated perfused human fetal liver. Int. J. Cancer, 8: 250 (1971).

10. KeNNEY, F. T., AND KRETCHMER, N.: Hepatic metabolism of phenylalnine during development. J. Clin. Invest., 38: 2189 (1959).

11. La Du, B. N., Howell, R. R., and Michael, P. J., Sober, E. K.: A quantitative micromethod for the determination of phenylalanine and tyrosine in blood and its application in the diagnosis of phenylketonuria in infants. Pediatrics, 31: 31, 39 (1963).

12. Levine, S. Z., Dann, M., And Marples, E.: A defect in the metabolism of tyrosine and phenylalanine in premature infants. III. Demonstration of the irreversible conversion of phenylalanine to tyrosine in the human organism. J. Clin. Invest., 22: 551 (1943).
13. Light, I. J., Berry, H. K., ANd Sutherland, J. M.: Aminoacidemia of prematurity. Amer. J. Dis. Childhood, 112: 229 (1966).

14. Lowry, O. H., Rosebrough, N. J., FarR, A. L., AND Randall, R. J.: Protein measurement with the Folin phenol reagent. J. Biol. Chem., 193: 265 (1951).

15. Menkes, J. H., ANd Avery, M. E.: The metabolism of phenylalanine and tyrosine in the premature infant. Bull. Johns Hopkins Hosp., 113: 301 (1963).

16. RYAN, W. L., AND ORR, W.: Phenylalanine conversion to tyrosine by the human fetal liver. Arch. Biochem. Biophys., 113: 684 (1966).

17. SNyderman, S. E.: The protein and amino acid requirements of the premature infant. In: Metabolic Processes in the Fetus and Newborn Infant, p. 128. Stenfert Kroese, Leiden, (1971).

18. I thank Dr. M. Kekomäki for his technical help in performing the fetal liver perfusion experiments.

19. The preliminary results of this study were presented at the XIII International Congress of Pediatrics in Vienna, August 1971.

20. This work was supported by the Association for the Aid of Crippled Children, New York, and the Sigrid Juselius Stiftelse, Helsinki.

21. Requests for reprints should be addressed to: Niels C. R. RÄrḦ̈, M.D., Department of Medical Chemistry, University of Helsinki, Helsinki, Finland.

22. Accepted for publication August 30, 1972. 